\title{
Existence of Untouchability towards Maari Theyyam-A Traditional Art Form of Kerala
}

\author{
P. Vijisha, E. K. Govinda Varma Raja* \\ School of Folklore Studies, University of Calicut, Kerala, India \\ Email:vijivijisha@gmail.com, "govindavarmaraja@gmail.com
}

Received 4 November 2015; accepted 27 March 2016; published 30 March 2016

Copyright (C) 2016 by authors and Scientific Research Publishing Inc.

This work is licensed under the Creative Commons Attribution International License (CC BY).

http://creativecommons.org/licenses/by/4.0/

c) (i) Open Access

\section{Abstract}

The renaissance movement led by Vaikundam Swamikal, Sreekumara Gurudevan, Ayyankali, Chattambi Swamikal, Dr. V. V. Velukkutty Arayan, Sahodharan Ayyappan, Swami Vakbhadananda and Swami Anantha Theertha was helping to eradicate untouchability from Kerala. The Temple entry proclamation by the erstwhile king of Travancore late Sri Chitra Thirunal Rama Varma Maharaja on his 24th birthday (12th November 1936) proclaimed that all Hindus by birth or faith, despite their caste will be allowed enter to all temples under the governance of Travancore state. The Temple Madayi Kavu ${ }^{1}$ is traditionally owned by Kolathiri King of Chirakkal. But it is controlled by the Malabar Devaswam Board, an authorised body of Government of Kerala. The goddess of this temple is the family deity of Travancore royal family. Maari Theyyam is a traditional ritual performance of Madayi Kavu. This ritual is not allowed to be observed in the premises of Madayi Kavu. All other Theyyams are allowed to be performed in the premises of the temple. Maari Theyyam is performed away from the temple premises. It is a kind of untouchability towards Maari Theyyam. Here, we try to examine the pros and cons of the untouchability of the ritual Maari Theyyam.

\section{Keywords}

Ritual, Untouchability, Prohibition

\section{Introduction}

The untouchability in the field of theyyam performance is depicted in the book "Folklore-Adhikaram Adhinive-

\footnotetext{
"Corresponding author.

${ }^{1}$ Madayi Kavu—A sacred grove with temple structure. The priest of the temple is belongs to pidara community. The helpers are known as "Moosathu".
} 
sam”² by A. V. Ajayakumar in the chapter “Ooruvilakku” (outcasting) [1]. In 1986, a shrine owned by the Thiyya community $^{3}$ named "Pattayath Puthiya Bhagavathi Kavu in Pappinisseri in Kannur district had an incident of untouchability. The traditional theyyam performer of the temple who belonged to the Vannan community ${ }^{4}$ scolded the Trustee member regarding the remuneration of the theyyam performance. The trustees quarrelled and they brought a Malaya community man to perform Puthiya Bhagavathy Theyyam. It was against tradition and ethics. At last, the political parties involved in the issue and settled it. In 1994, Manakkad Raman Peruvannan from Ezhom performed Muthappan Vellattam Theyyam in Nirichan Gopalan's house, who belonged to Pulaya community ${ }^{5}$. But, the trustees of Cheerumba ${ }^{6}$ kavu temple which belonged to the Thiyya community didn't allow Raman Peruvannan to perform Theyyam in the temple. Even though he was the right holder to perform Theyyam there, because he performed Theyyam in a house which belonged to a Pulaya person, he was outcasted. Because of this, Raman Peruvanna sued the temple Trust in a special court for Other Backward Castes and got a favourable result. But he didn't perform in that temple again.

\section{Maari Theyyam and Untouchability}

History is the documentation of the past. It is the description of authentic data but the historians failed to understand the relevance of data which they collected for the creation of history. So we have omissions and dropouts. In the feudal social order, the historians described the history as of landlords. They have not considered the agrarian history and the peasant history. The lack of documented evidence was the main reason for the omission. According to the document in the revenue records, the names of the landlords are visible. The tenant's name is not there. At the same time, the list of tenants was kept in the landlord's house. So the agrarians were not in the records but the agrarian movement of the past and the victims of feudal system were depicted in rituals, myths and legends.

The ritual performance of Chimmaanakali ${ }^{7}$ explains the transformation of primitive communism to feudalism and role of merchants and their victims.

The myth of Kuttichathan ${ }^{8}$ explains the fight for the rights of agrarian peasants.

The Kathirvanoorveeran ${ }^{9}$ Theyyam explains trade and commerce and the competition. Let us deconstruct the history with the evidence of folk-narratives. At present we are proud of equality. Practically, it is not a reality.

In the temple entry proclamation, His Highness Sri Chithira Thirunal Maha Raja of Travancore proclaimed the temple entry for the devotees of Hindu religion without any caste prejudices. Lower caste people also got the right to enter the temples. Nowadays, any Hindu can enter the temple without any prejudices, but certain communities are not allowed to perform their ritual performance in the premises of temple. The ritual Theyyam is very popular in North Malabar. Madayi kavu is the Goddess of the Chirakkal dynasty. The same Goddess is also the main deity of the Travancore royal family, due to the adoption from Kolathiri royal family to Travancore

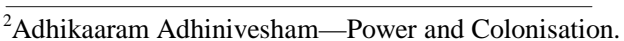

${ }^{3}$ Thiyya community —A backward community of Malabar region of Kerala. Their Traditional occupation was Toddy tapping, agriculture and folk medicine.

${ }^{4}$ Vannan community—One sect of traditional Theyyam performers according to Government censud, this group included in the scheduled caste.

${ }^{5}$ Pulaya community — A community which was considered as the lowest strata of the caste system.

${ }^{6}$ Cheerumba-The goddess of smallpox.

${ }^{7}$ Chimmanakkali-Satiric folk drama of Pulaya community in the North Malabar. It is a part of the ritual Kenthron Paattu (A magical ritual performed at the time of pregnancy). There are three characters in this performance. Mavilan, Mappilan and Mavilathi. The folk instrument "Thudi" is used for performance. When mavilan went to traditional agriculture at forest, his wife was perverted by Muslim merchent.

${ }^{8}$ Kuttichathan—One among the "Mandramoorthikal" (the God/goddess that can be implored through meditation and made to obey the magical rituals). It is a Theyyam in North Malabar. The higher myth is described as follows-Kuttichathan was the son of siva and Parvathy when they disguised as Valluva and Valluvathy (Valluva is the title name of Pulaya caste). The wife of Kalakad Namboothiri worshiped Lord Siva for a child. Lord Siva gave this kid to Kalakad Namboothiri. Kuttichathan is very powerful and fought against injustice. In the lower myth he was a cowboy of Kalakat Illam. When the wife of Kalakad Namboothiri has given the chaff instead of paddy to the labourers. He questioned. The assistants of the Kalakad Killed Kuttichan and pulled on fire. The folk celebrates the Matyre of Kuttichathan with devotion.

${ }^{9}$ Kathirvannur Veeran-A brave fighter Theyyam of North Malabar. Mangattu Mannappan became the Kathuvannur Veeran Theyyam. Chakkiyamma of Methali Illam got a he-baby with the blessing of goddess Chuzhali Bhagavathy. He learned everything about martial arts and played with his friends. It was not liked by his father. He ordered his wife not to give any food to him. He left the home with a bow and an arrow. He wished to trade and commerce with his friends. But they cheated him. They gave him toddy and left. Then he reached uncle's house at Kathuvannur and married Chemmarathi. One night he could not return back from market. When he reached home, Chemmarathi ignored. Some bad omen was seen. At the same time Kudaku people challenged him to fight. He won over the fight but damaged his ring and small finger. He returned back to the battlefield. On the way, the enemies killed him from the backside. He became martyr. This Theyyam is performed by Vannan community.
} 
royal family. The untouchability due to caste was vanished, but untouchability in rituals is still continuing, for which the case study of Maari Theyyam of Madayi kavu is a living proof.

Maari Theyyam is a ritual performed by the Pulaya community of North Malabar. It is a traditional right of the Pulaya community. It starts in the mid of the Malayalam month of Karkkidakam, which is approximately on the 1st or 2nd of August. There are six Theyyams in this group, namely Maari Kaliyan, Mamaaya Kaliyan, Maari Kalichi, Mamaaya Kalichi, Maari Kuliyan and Mamaaya Kuliyan. The costumes of the Theyyam are made up of tender coconut leaves. Both Kuliyans wear masks.

Legend says that Maari and Mamaaya came from Aryarnadu, which means North India. These evil Gods trickily got into the wooden ship (Marakkalam) of the Goddess, who travelled from Aryan region to North Kerala. Both Maari and Mamaaya got down from the ship at Valapattanam. These evil gods spread calamity in the region. The rituals in temples also got postponed due to the impact of evil deeds. In that situation, an astrologer was brought to Madayi kavu and was made to think about the problem. The astrologer observed the zodiac sign and found out a solution. The village was conquered by evil Gods. To avoid the evil Gods, they brought the traditional magician Polla, a Pulaya youth to do the rituals. The astrologer pointed out the date and time of the proposed ritual to be performed by Polla. The ritual was to worship and perform Maari Theyyam after the noon on the 16th day of Karkkidaka month and remove the evil Gods. He performed it and in the consecutive days, the same Theyyam wandered in every nook and corner of the villages and removed the evil Gods. At last, Maari Theyyam was given a sendoff in the waters of the river. These Maari Theyyams were not performed in the premises of madayi kavu while all other Theyyams were performed in the courtyard of Madayi kavu. According to an artist who performs Maari Theyyam, it was not due to untouchability. He says, "Long back, the temple authority decided a fixed place for each and every Theyyams. We got a place which is somewhat far away from Madayi kavu temple towards North East. They also argued that Maari Theyyam is the part and parcel of temple rituals. It didn't start recently. It is a long tradition and we have no right to change the rituals.

At the same time, there were changes in some rituals. Up to the 1960s, it was a common scene that the drummers of Malaya community, who accompanied the procession were not allowed to enter inside the boundaries of the temple. This untouchability was eliminated after the implementation of the Land Reform Act.

Usually, the Kadaamkott Maakapothi ${ }^{10}$, a Goddess Theyyam, was performed only in Chala. But recently, it was performed in Kadaamkott Tharavadu. According to the myth, it was not performed in Kadaamkott Tharavadu due to the martyr of Kadaamkott Maakam and her kids. There, the rituals were violated.

In Elavoor Bagavati temple, there is a ritual called Elavoor Thookkam. This performance is very vigorous; to hang a human being on a metal hook which is stitched on the back skin of the man and hanged using a 20 feet tall pillar instead of the ritual Poomoodal, which means covering the goddess idol with flowers.

The offering Panjagavya is made using the cow dung, urine, ghee and butter milk of the same cow. But nowadays, it is made out of milk, which is bought from a booth and kept in the refrigerator for three or four days.

The devotees of God Ayyapa usually visited the temple with 41 days of penance. But nowadays, most of the devotees visit without observing penance, instead they wear instant costumes and sandal chain with Ayyappa's locket and offering kit is arranged by a temporary Guruswamy (Senior most Ayyappa devotee with penance). Usually, the Theyyams do not receive sacred weapons from the Brahmin priest directly. It is handed over by the mediator, like a Nambiar or a Nair. The offerings are not directly given to the Theyyam and flowers and powder is not collected directly from the Theyyam by Brahmins, but through mediators.

Even though during the performance the Theyyam is considered as god, the Theyyam is not allowed to enter the sanctum sanctorum of the temple.

The majority of the folk are not ready to break the rituals. By the passage of time, it is necessary to break certain norms and rituals. If anybody is ready to question the untouchable attitude towards Maari Theyyam or any other Theyyam, they can overcome the untouchability with the same remedies. There are possibilities to change the ritual with another ritual advised by the astrologer. The contradiction in the case of untouchability which is practised by the performance towards Maari Theyyam is very remarkable on account of the temple entry proclamation which was proclaimed by the devotee of Maadayi kavu Bagavati by late Sree Chithira Thirunaal Maha

\footnotetext{
${ }^{10}$ Kadamgot Maakkapothi-She was born as a single daughter of Kadangot Unichiriya with twelve brothers. All of them loved her much. She was married a man who won over the contest arranged by her brothers. But she was not liking him initially. She delivered a boy Chandu and a girl Cheeru. When her brothers went for war instructed by Kolathiri. Meanwhile the sisters-in-law cheated her with an oil merchant. They were murmuring against the pervasion of Maakkam. The brothers misunderstood their sister and sent her to a festival. On the way at chala she took water from a well to drink. At that time brothers killed Maakkam and her kids. All of them became Martyrs and became Gods.
} 
Raja.

\section{Conclusion}

Even though public movements lead to a reniassance to ablolish untouchability, authorities still practice untouchability. That is why Maari Theyyam is still being performed far away from Madayi Kavu temple which has the family deity of Sri Chitra Thirunal Maharaja, who made temple entry proclamation to all the public. This reveals that even though individuals are protected legally from untouchability, rituals like Maari Theyyam are still facing it, even legally.

\section{References}

[1] Ajayakumar, A.V., Folklore, Adhikaram and Adhnivesam (2008) ED Club. The Zamorins' Guruvayurappan College, Calicut. 